\title{
Upaya Kepala Madrasah dalam Mengembangkan Lembaga Pendidikan di Madrasah Ibtidaiyah Nashriyah Desa Tanjung Baru
}

\author{
Hidayat ${ }^{1}$, Ibrahim ${ }^{2}$ \\ 1,2UIN Raden Fatah, Palembang, Indonesia \\ hidayatd116@gmail.com
}

\begin{abstract}
This study aims at determining the efforts of the Head of Madrasah Ibtidaiyah (MI), to find out the development of MI Nashriyah under the leadership of the current head of MI Nashriyah, Tanjung Baru Village, Tanjung Lubuk District, Ogan Komering Ilir Regency. This research is a descriptive study using a qualitative approach. Data collection methods used included: a) interviews, b) observation, and c) documentation. The data were collected through the three techniques which were organized, interpreted, and analyzed repeatedly, then analyzed with data analysis techniques. Furthermore, the credibility of the data was checked by using the data validity test, namely, triangulation. The findings in this study are: the efforts done by the head of Madrasah Ibtidaiyah Nashriyah in developing this institution covered the provision of facilities and infrastructure, such as adding student learning facilities, repairing and adding building for student learning, providing special transportation to pick up students. The development of MI Nashriyah under the leadership of the current Head of Ibtidaiyah Nashriyah Madrasah, is that the existence of a special service for students who have not been able to read the Al-Qur'an (BTA) properly and correctly, and the increase of the number of new students each year, periodical supervision on teachers during the process of learning, the increase of student academic achievement, and the increase of the number of teaching staffs (teachers).
\end{abstract}

Keywords: head of madrasah, development of educational institutions

\begin{abstract}
Abstrak. Penelitian ini bertujuan penelitian ini untuk mengetahui upaya Kepala Madrasah Ibtidaiyah (MI), mengetahui perkembangan MI Nashriyah di bawah kepemimpinan kepala MI Nashriyah Desa Tanjung Baru Kec. Tanjung Lubuk Kab. Ogan Komering Ilir. Penelitian ini merupakan penelitian deskriptif dengan menggunakan pendekatan kualitatif. Metode pengumpulan data yang digunakan meliputi: a) wawancara, b) observasi, dan c) dokumentasi. Data yang terkumpul melalui ketiga teknik tersebut diorganisasi, ditafsir, dan dianalisis secara berulang-ulang, selanjutnya dilakukan analisis dengan teknik analisa data. Selanjutnya kredibilitas data dicek dengan menggunakan uji keabsahan data yaitu, triangulasi. Temuan dalam penelitian ini adalah: Upaya yang kepala Madarasah Ibtidaiyah Nashriyah lakukan dalam mengembangkan lembaga ini adalah, pengadaan sarana dan prasarana, seperti penambahan fasilitas belajar siswa, memperbaiki sekaligus menambah gedung/lokal belajar siswa, menyediakan transfortasi khusus antar jemput siswa. Perkembangan MI Nashriyah di bawah kepemimpinan Kepala Madrasah Ibtidaiyah Nashriyah, adalah pelayanan khusus terhadap siswa yang belum bisa membaca tulis al-Qur'an (BTA) dengan baik dan benar, meningkatnya jumlah siswa yang masuk setiap tahun, melakukan supervisi secara berkala pada guru saat proses pembelajaran berlangsung, meningkatnya prestasi siswa secara akademik, dan meningkatnya jumlah tenaga pengajar (guru).
\end{abstract}

Kata Kunci: kepala madrasah, perkembangan lembaga pendidikan

\section{PENDAHULUAN}

Sekolah merupakan sebuah organisasi, dan organisasi merupakan sistem sosial. (Supardi, 2018: 1). Ciryl Glasse menyatakan madrasah adalah sekolah... 
tempat belajar... jamak; madaris. (Glasse, 1996: 240). Sekolah adalah lembaga yang bersifat kompleks dan unik. Bersifat kompleks karena sekolah merupakan organisasi di dalamnya terdapat berbagai dimensi yang satu sama lain saling berkaitan dan saling menentukan. Sedangkan sifat unik, menunjukkan bahwa sekolah sebagai organisasi memiliki ciri-ciri tertentu yang tidak dimiliki oleh organisasi-organisasi lain. Ciri-ciri yang menempatkan sekolah memiliki karakter tersendiri, di mana terjadi proses belajar mengajar, tempat terselenggaranya pembudayaan kehidupan umat manusia (Wahjosumidjo, 2010:81).

Lingkungan sekolah dewasa ini menghadapi berbagai tantangan yang semakin dinamis seiring dengan semakin berkembangnya budaya masyarakat modern dan semakin cepatnya perkembangan teknologi manufaktur, komunikasi, informasi, serta tuntutan pemangku kepentingan (stakeholders) tentang pentingnya peningkatan kualitas pendidikan melalui pembenahan dan peningkatan kualitas sekolah. Berkenaan dengan hal tersebut, faktor yang paling dianggap paling potensial dalam menciptakan keunggulan sekolah terletak di tangan kepemimpinan kepala sekolah (Karwati dan Donni Juni Priansa, 2018: 236).

Kepala madrasah merupakan faktor penentu sukses tidaknya kegiatan madrasah. Kualitas madrasah ditentukan oleh kualitas kepemimpinan kepala madrasah (Ghozali, 2007:84). Sebagai pemimpin kepala madrasah memiliki kebebasan untuk menyampaikan usulan, rencana dan kegiatan-kegiatan yang bersifat pribadi maupun kelompok dalam rangka pencapaian tugas. Sehingga tercapainya tujuan perubahan-perubahan di madrasah. Menurut Tilaar, H.A.R. dalam bukunya bahwa kepala sekolah harus mampu menciptakan perubahan bagi sekolah dan meraih tujuan lembaga yang ia pimpin, ia juga menerima tanggung jawab dari staf, siswa dan guru-guru serta menyiapkan diri bila kelompok memerlukan arahan, dan keinginan untuk secara efektif melakukan interaksi dengan kelompok dan membinanya (Tilaar, 2003: 167). Jadi, bisa disimpulkan bahwa seorang pemimpin mampu mengambil kebijakankebijakan yang lebih mengedepankan pelayanan dalam memenuhi dan memfasilitasi semua kebutuhan guru, staf dan para stakeholders, sebab kepala madrasah memegang tanggung jawab yang besar bagi perkembangan madrasah atau sekolah yang dipimpinnya.

Untuk memperoleh dukungan dan partisipasi masyarakat kepala madrasah harus mampu melakukan komunikasi edukatif dan dialog-dialog yang bermakna bagi tumbuhnya saling percaya antara pimpinan madrasah dengan masyarakat. Melalui komunikasi dan dialog juga dapat dibangun kemitraan sejajar yang bermuara kepada membangun masyarakat madrasah 
secara kebersamaan. Madrasah adalah dari masyarakat, oleh masyarakat dan untuk masyarakat. Pimpinan madrasah bersama-sama guru-guru dan staf adalah pelayan yang diberi amanat untuk melaksanakan pendidikan dan pengajaran sesuai dengan harapan dan kebutuhan masyarakat (Ghozali, 2007:67).

Kepala sekolah yang berhasil apabila mereka memahami keberadaan sekolah sebagai organisasi yang kompleks dan unik, serta mampu melaksanakan peranan kepala sekolah sebagai seseorang yang diberi tanggung jawab untuk memimpin sekolah (Wahjosumidjo, 2010:81), sebagai seorang tokoh pimpinan yang menentukan suatu organisasi kepala sekolah diberi tanggung jawab untuk memimpin dan menggerakkan individu-individu untuk melaksanakan tugas dan tanggung jawab masing-masing bagi mencapai hasil sesuai dengan tujuan yang dikehendaki (Supardi, 2018 :39).

Salah satu kekuatan efektif dalam pengelolaan sekolah yang berperan bertanggung jawab menghadapi perubahan adalah kepemimpinan kepala sekolah, yaitu kepala sekolah yang mampu memprakarsai pemikiran baru di dalam proses interaksi di lingkungan sekolah dengan melakukan perubahan atau penyesuaian tujuan, sasaran, konfigurasi, prosedur, input, proses atau output dari suatu sekolah sesuai dengan tuntutan perkembangan (Wahjosumidjo, 2010: VII). Oleh karenanya sekolah mestinya tidak tertinggal oleh perubahan, tetapi justru sebagai agen suatu perubahan itu. Banyak sekali perkembangan dan perubahan lingkungan yang tidak dapat direspon oleh sekolah, disebabkan oleh cara berpikir para kepala sekolah yang kaku, kurang fleksibel yang disebabkan oleh visi yang dangkal, tanpa mampu memandang jauh kedepan. Fleksibel suatu sekolah yang perlu menjadi pemikiran para kepala sekolah adalah bagaimana agar sekolah dapat menangkap aspirasi masyarakat, sehingga program-program sekolah dapat disesuaikan dengan kebutuhan masyarakat yang dilayani. Kekakuan layanan sekolah seperti yang selama ini terjadi, justru hanya menjauhkan sekolah dari masyarakat (Sujanto, 2007: 72).

Kepala madrasah diangkat melalui prosedur serta persyaratan tertentu yang bertanggung jawab atas tercapainya tujuan pendidikan melalui upaya peningkatan profesioanalisme tenaga kependidikan yang mengimplementasikan meningkatkan prestasi belajar peserta didik. Kepala madrasah yang profesional akan berpikir untuk membuat perubahan tidak lagi berpikir bagaimana suatu perubahan sebagaimana perubahan adanya sehingga tidak terlindas oleh perubahan tersebut. Untuk itu mewujudkan kepala sekolah yang profesional tidak semudah membalikkan telapak tangan, semua itu butuh proses yang panjang (Nazaruddin, 2007: 88). Jadi, bisa 
dipahami bahwa seorang pemimpin madrasah hendaklah selalu meningkatkan organisasi pendidikan, sudah seharusnya seorang pemimpin memperhatikan kebutuhan-kebutuhan baik secara internal maupun eksternal madrasah, mampu melakukan perubahan terhadap organisasi yang dipimpin dalam hal ini madrasah/sekolah, sebab seorang pemimpin memiliki peran yang sangat urgen dalam meningkatkan perkembangan madrasah/sekolah.

Berdasarkan data yang ada di MI Nashriyah bahwa Saat ini telah melakukan berbagai perbaikan sehingga madrasah pun mengalami perkembangan yang signifikan, baik dari aspek sarana dan prasarana, tenaga pendidik (guru), tenaga kependidikan dan peserta didiknya, jika dibandingkan dengan tahun yang sebelumnya, siswa-siswinya sangat sedikit, sarana dan prasarana belum memadai, begitupun tenaga pendidik dan kependidikannya belum memiliki kualifikasi pendidikan starata 1 .

Selain itu keadaan sekolahnya sangatlah memprihatinkan, tidak layak untuk dijadikan tempat belajar. Maka berangkat dari kondisi yang nyata di atas, penelitian ini akan membahas tentang upaya yang dilakukan oleh kepala madrasah dalam meningkatkan mutu lembaga pendidikan MI Nashriyah desa Tanjung Baru Kecamatan Tanjung Lubuk Kabupaten Ogan Komering Ilir (OKI).

\section{KAJIAN LITERATUR}

Penerapan Kepemimpinan Kepala Sekolah dalam Meningkatkan Kinerja Guru Pada Jenjang Sekolah Menengah Pertama (SMP) Menyimpulkan bahwa Kepemimpinan kepala sekolah yaitu proses pemahaman seorang guru dalam memberikan arti mengenai kepemimpinan yang dijalankan oleh kepala sekolah berdasarkan pengamatan, pengalaman, perhatian dan kepercayaan yang terseleksi selama menjadi guru. Dapat disimpulkan bahwa dalam tubuh sekolah, kepemimpinan hendaknya dikembangkan diantara semua guru, di semua tingkatan. Semua guru hendaknya berpartisipasi dalam mengembangkan visi dan misi sekolah menghadapi era masa depan. Semua anggota kelompok organisasi hendaknya rela menerima tanggung jawab baru, mengambil resiko, membina konsensus, dan saling percaya mempercayai di antara kolega. yakin bahwa semua orang memiliki keterampilan memimpin yang ada di dalam diri masing-masing, dan keterampilan tersebut dapat dikembangkan. Kepemimpinan bukan sesuatu yang mistik, akan tetapi terdiri atas sejumlah keterampilan yang dapat dilatih dan dikembangkan, walaupun disadari bahwa ada faktor bakat alami tertentu yang melekat pada setiap orang. Pemimpin adalah seseorang yang mempunyai kemampuan untuk memengaruhi perilaku orang lain dalam kerjanya dengan menggunakan kekuasaan. Kekuasaan adalah kemampuan untuk mengarahkan dan 
memengaruhi bawahan sehubungan dengan tugas-tugas yang harus dilaksanakannya (Syamsul, 2017).

Strategi Kepala Madrasah dalam Meningkatkan Mutu Pendidikan Pada MIN Buengcala Kecamatan Kuta Baro Kab Aceh Besar. Strategi kepala madrasah dalam upaya meningkatkan efektivitas pembelajaran yang dilaksanakan guru pendidikan MIN Buengcala Kecamatan Kuta Baro Kabupaten Aceh Besar adalah menyusun roster pembelajaran awal tahun ajaran, merumuskan peraturan madrasah, membuat perangkat pembelajaran, mengembangkan kemampuan profesionalisme guru, dan mengarahkan guru untuk selalu ada buku penilaian siswa dan absen, agar menjadi ajuan untuk perkembangan siswa itu sendiri. Dalam upaya meningkatkan kompetensi guru mutu pendidikan pada MIN Buengcala Kecamatan Kuta Baro Kabupaten Aceh Besar, kepala madrasah telah melakukan pemanfaatan berbagai sumber daya yang ada. Terutama pelatihan kurikulum 2018 bagi guru-guru, mengikut sertakan guruguru dalam KKG (Kelompok Kerja Guru) digugus Tungkop dan memotivasi guru untuk selalu memahami siswa dan dicintai oleh siswa itu sendiri dengan menerapakan pembelajaran yang menyenangkan bagi peserta didik. Strategi Kepala Madrasah dalam mengatasi hambatan untuk peningkatan mutu pendidikan pada MIN Buengcala Kecamatan Kuta Baro Kabupaten Aceh Besar antara lain dengan lebih melibatkan masyarakat dalam program madrasah melalui komite madrasah baik untuk peningkatan mutu maupun memaksimalkan penggunaan sarana dan prasarana yang ada untuk mengatasi permasalahan yang dirasakan oleh pihak madrasah (Hadi, 2018).

Kepemimpinan Kepala Madrasah dalam Inovasi Manajemen Pendidikan di MTs N DIWEK Jombang Kepala madrasah sudah melakukan fungsi manajemen pendidikan yaitu planing (perencanaan), organizing (organisasi) motivating (penggerakan) dan controling (pengawasan). Usaha yang di lakukan kepala madarasah dalam melakukan inovasi manajemen pendidikan di MTsN Diwek jombang adalah: Meningkatkan mutu tenaga pendidikan, meningkatkan kedisiplinan guru, menyediakan sarana prasarana: ruangan kelas, laboratarium, dan perpustakaan, melaksanakan program pengelompokan siswa, dan pelaksanaan program kegiatan ekstrakurikuler dan keagamaan. Adapun faktor pendukung dan penghambat inovasi manajemen pendidikan di MTs N Diwek Jombang adalah: Faktor pendukung adalah peran aktif para guru dalam membantu pelaksanaan inovasi manajemen pendidikan, dan sarana prasarana yang ada dapat dimanfaatkan dengan sebaik mungkin dan faktor penghambat adalah masih ada beberapa guru yang tidak berkualifikasi, dan sebagai solusinya adalah mewajibkan para 
guru yang belum berkualifikasi untuk mengikuti seminar, diklat, MGMP, dan KKG (Hajijah \& Mustofa, 2017).

\section{METODE PENELITIAN}

Jenis data yang dihimpun adalah data kualitatif. Data kualitatif adalah penelitian tentang riset yang bersifat deskriptif dan cenderung menggunakan analisis dengan pendekatan sosiologis. Karena, dalam penelitian sosial menggunakan format deskriptif bertujuan untuk menggambarkan, meringkas berbagai kondisi, berbagai situasi atau berbagai variable yang timbul di masyarakat yang menjadi objek penelitian. Kemudian menarik ke permukaan sebagai suatu ciri atau gambaran suatu kondisi ataupun situasi tertentu (Bungin, 2001: 48), maka dalam hal ini meliputi tentang pola kepemimpinan kepala MI Nashriyah dan perkembangan MI Nashriyah Desa Tanjung Baru Kec. Tanjung Lubuk Kab. Ogan Komering Ilir. Sumber data primer adalah data yang diambil langsung dari peneliti kepada sumbernya, tanpa adanya perantara (Mukhtar, 2009: 86). Sumber data penelitian adalah kepala MI Nashriyah, wakil kepala madrasah, guru kelas, guru bidang studi. Sumber data sekunder adalah data yang bukan diusahkan sendiri pengumpulannya oleh peneliti (Mukhtar, 2009: 90). Sumber data ini diperoleh dari buku-buku, jurnal dan dokumentasi serta arsip-arsip resmi.

Teknik pengumpulan data yakni melalui observasi dilakukan dengan cara mengamati langsung terhadap obyek yang diteliti terkait dengan upaya yang dilakukan kepala MI Nashriyah dengan metode ini penelitian akan lebih objektif dan diharapkan dapat memperoleh data tentang upaya dan bagaimana perkembangan yang dilakukan kepala MI Nashriyah Desa Tanjung Baru Kec. Tanjung Lubuk Kab. OKI. Wawancara, metode ini digunakan untuk mendapatkan informasi. Wawancara ini dilakukan terhadap kepala MI Nashriyah, wakil kepala madrasah, guru kelas dan guru bidang studi, untuk mengetahui upaya kepala MI Nashriyah, perkembangan MI Nashriyah, dan dokumentasi dilakukan untuk mengetahui jumlah guru, jumlah siswa, sarana prasarana, letak geografis, struktur organiasai, sejarah sekolah serta data lain yang dianggap perlu.

Pengolahan data, data yang terhimpun dari lapangan (obyek penelitian) lalu diklasifikasikan sesuai dengan permasalahan yang ada. Analisis data, analisis data merupakan proses mencari dan mengatur secara sitemetis transkrip wawancara, catatan lapangan dan bahan-bahan lain yang dipahami oleh peneliti. Kegiatan analisis data dilakukan dengan menelaah data, menata data, membagi menjadi satuan-satuan yang dapat dikelola, mensintesis untuk 
mencari pola, menemukan apa yang bermakna dan apa yang di teliti dan melaporkan secara sistemis.

1. Reduksi Data

Reduksi data adalah proses pemilihan, pemusatan perhatian, penyederhanaan, pengabstrakan dan transpormasi data besar yang muncul dari catatan-catatan tertulis di lapangan (Saebani, 2008: 95-96).

2. Penyajian Data

Penyajian data yakni penyajian sekumpulan informasi sistematis yang memberi kemungkinan adanya penarikan kesimpulan dan pengambilan tindakan (Saebani, 2008: 96).

3. Verifikasi

Dari permulaan pengumpulan data, penelitian kualitatif mulai memutuskan apakah "makna" sesuatu, mencatat keteraturan, pola-pola, penjelasan, konfigurasi yang mungkin, alur kausal, proposisi-proposisi. Atau dengan usaha untuk membuat replikasi suatu temuan dalam rangkaian data yang lain. secara singkat, makna muncul dari data yang telah teruji kepercayaannya, kekuatannya, konfirmabilitasnya yaitu validitasnya (Emzir, 2010: 50).

Kemudian menggunakan triangulasi yaitu suatu cara memandang permasalahan/obyek yang dievaluasi dari berbagai sudut pandang, bisa dipandang dari banyaknya metode yang dipakai atau narasumber data. Tujuannya agar dapat melihat obyek yang dievaluasi dari berbagai sisi, triangulasi dilakukan untuk mengejar atau mengetahui kualitas data yang dipertanggungjawabkan (Arikunto, 2007: 136).

\section{HASIL DAN PEMBAHASAN}

Pembahasan ini akan dilakukan penulis dengan merujuk pada hasil temuan yang diperoleh dari lapangan melalui wawancara, observasi dan dokumentasi. Pada uraian ini peneliti akan ungkap dan paparkan mengenai hasil penelitian dengan cara membandingkan atau mengkonfirmasikannya. Upaya Kepala Madrasah Ibtidaiyah Nashriyah yaitu:

1. Fasilitas pembelajaran

Langkah pertama yang menjadi tolok ukur kepala madrasah dalam mengembangkan lembaga adalah haruslah dengan sarana dan parasana yang lengkap. Berdasarkan penuturan kepala madrasah bahwa upaya yang dilakukannya adalah membangun gedung baru dan memberikan perlengkapan sekolah berupa bantuan pakaian kepada siswa-siswi nya secara gratis. 
Fasilitas pembelajaran adalah alat-alat yang menunjang proses pembelajaran baik yang langsung maupun secara tidak langsung, fasilitas dapat berbentuk sebagai berikut: Fasilitas penunjang langsung; yaitu fasilitas yang dapat berbentuk media pembelajaran yang ada di MI Nashriyah berbentuk gambar, seperti ada gambar tentang silsilah nabi Muhammad, dan ini digunakan ketika dalam pembelajaran sejarah kebudayaan Islam, maupun alat peraga, seperti praktek shalat, ataupun berwudhu', buku paket, tinta, kapur tulis, spidol, papan tulis, whiteboard, blackboard, dan lain-lain.

Teknologi informatika komputer di MI Nashriyah belum terealisasi dikarenakan belum ada dana yang memadai untuk pengadaannya. Sebab untuk mengadakan ruangan yang khusus akan membutuhkan dana yang besar. Menurut kepala madrasah bahwa memang dalam pengadaan TIK masih belum ada dana yang pasti, oleh karena itu belum teralisasi memang cita-cita untuk membangun ruangan TIK sudah ada, namun kendalanya masih belum memiliki dana yang cukup.

Faktor pendukung berkembangnya fasilitas pendidikan yang ada di MI Nashriyah disebabkan karena adanya bantuan dari pemerintah untuk membenahi madrasah, kemauan kepala madrasah dalam membangun madrasah. Seperti halnya apa yang diungkapkan Ibu Rusdiana bahwa kepala madrasah selalu berusaha untuk memajukan dan mengembangkan madrasah, melalui sumbangan dari dirinya sendiri, memintak bantuan ke instansi pemerintahan.

Selain itu juga faktor yang menentukan perkembangan di MI Nashriyah adalah sikap kepedulian yang ada pada kepala madrasah, hasil observasi pada tanggal 8 Maret 2018 bahwa kepala madrasah melakukan pemantauan terhadap gedung yang sedang dibangun. Jadi, bisa dipahami bahwa kemajuan dari aspek fasilitas yang ada di MI Nashriyah didukung oleh adanya keinginan/kemauan dari kepala madrasah dalam membangun dan mengembangkan madrasah, adanya bantuan dari pemerintahan dalam membangun madrasah.

2. Membenahi Visi dan Misi Madrasah

Dalam hal memformulasikan visi misi kepala madrasah tidak pernah melibatkan para guru dan stafnya, visi misi madrasah mengharapkan semua siswa unggul dalam prestasi, berbudaya dan berakhlak mulia.

Sedangkan misi di Madrasah mencetak manusia Indonesia menjadi insane berkualitas dan bertaqwa kepada Allah Swt. Mengoptimalkan kegiatan proses belajar mengajar dan membimbing tenaga pendidik. Menjadi contoh yang baik bagi masyarakat sekitarnya. 
Visi misi inilah yang dibentuk kepala madrasah dengan mengoptimalkan seluruh aspek yang ada di madrasah, hal yang dilakukan kepala madrasah dalam meningkatkan kualitas madrasah meliputi peningkatan siswa, gedung, guru, fasilitas yang ada di madrasah, sehingga dalam mewujudkan madrasah yang menjadi contoh dapat dijalankan secara optimal.

Dalam konsep manajamen kepala madrasah ketika merancang visi dan misi, maka kemampuannya dalam membuat konsep sebagai bahan acuan dalam membina dan mengambangkan madrasah ke arah yang lebih baik.

Berdasarkan penjelasan di atas bisa dipahami bahwa faktor yang mendukung dari kemajuan madrasah adalah tidak lepas dari peran serta pimpinan dalam membina dan mengembangkan madrasah, aspek sarana dan prasarana, siswa, tenaga pendidik. Akan tetapi hal yang menjadi kendala dari perkembangan MI Nashriyah adalah siswa-siswi, tenaga pendidik, sarana dan prasarana yang ada di MI Nashriyah, proses pembelajaran dan lain sebagainya.

3. Kedisiplinan

Berdasarkan dokumentasi yang ada pada MI Nashriyah bahwa kepala MI Nashriyah membuat rambu-rambu agar para bawahannya menanamkan budaya malu: malu karena datang terlambat/pulang cepat, malu karena berbuat salah, malu karena melihat rekan sibuk melakukan aktivitas, malu karena melanggar peraturan, malu karena bekerja tidak berprestasi, malu karena tugas tidak terlaksana/tidak selesai tepat waktu, malu karena tidak berperan aktif dalam mewujudkan kebersihan lingkungan kantor/sekolah.

Siswa-siswi diwajibkan untuk masuk ke kelas jam 07:10-12:15. Begitupun tenaga pengajarnya harus masuk tepat waktu, dan jika gurunya terlambat/melanggar peraturan yang telah ditetapkan oleh kepala madrasah akan mendapatkan punishment berupa teguran langsung secara lisan, penurunan intensive guru, dan terakhir dikeluarkan dari sekolah/madrasah.

Selain itu juga berdasarkan hasil observasi tanggal 3 April 2018 bahwa dalam meningkatkan kedisiplinan para guru dan staf kepala madrasah selalu mengawasi para guru secara langsung dan memeriksa absensi para guru.

Faktor yang menentunkan peningkatan kedisiplinan yang ada di sekolah adalah tidak lepas dari peran kepala madrasah, sebab kepala madrasah merupakan menjadi panutan, memberikan arahan dan petunjuk 
kepada bawahannya agar disiplin. Gaya kepemimpinan kepala madrasah juga mempengaruhi dalam meningkatkan kedisiplinan para guru dan staf.

Sikap kedisiplinan guru dan staf yang ada di MI Nashriyah juga dipengaruhi oleh peraturan-peraturan yang dibuat oleh kepala madrasah, sehingga guru dan staf mengikuti semua peraturan yang ditetapkan. Menanamkan sikap rasa malu ketika tidak datang tepat waktu, dan akan mendapatkan hukuman berupa menurunnya intensive bulanan jika tidak mengikuti peraturan yang ada di MI Nashriyah.

Selain itu menurut Rusdiana mengatakan bahwa sebenarnya kemajuan madrasah itu berada di tangan kepala madarsah, sebab pemimpin harus menjadi panutan, jika seorang pemimpin tidak memiliki kedisiplinan tentu bawahannyapun mengikuti sikap pemimpin. Jadi, bisa dipahami bahwa kedisiplinan itu akan terjadi karena ada peraturanperaturan yang ditetapkan di madrasah, selain itu tidak terlepas dari peran seorang pemimpin yang mampu membimbing dan membina bawahannya dalam mengembangkan sekolah/madrasah.

\section{Perkembangan MI Nashriyah di Bawah Kepemimpinan Kepala MI Nashriyah Desa Tanjung Baru Kec. Tanjung Lubuk Kab. Ogan Komering Ilir}

Kepala madrasah sebagai seorang yang telah diberi wewenang untuk memimpi suatu lembaga pendidikan, harus bertanggung jawab terhadap setiap penyelenggaraan pendidikan di madrasah, maju mundurnya suatu lembaga pendidikan tergantung pada peran kepala madrasah termasuk juga peningkatan dalam pengadaan sarana dan prasarana pendidikan, siswa, tenaga pendidik (guru dan non guru), membangun hubungan dengan masyarakat sekitar.

Menurut kepala madrasah bahwa dalam pengembangan madrasah bisa dilihat dari aspek sarana dan prasarana, meningkatnya siswa-siswi, tenaga pendidik di antara perkembangan madrasah Ibtidaiyah Nashriyah adalah:

1. Fasilitas di MI Nashriyah

Sarana atau disebut dengan fasilitas pendidikan, maka sarana yang ada di MI Nashriyah adalah berupa ruangan belajar, meja, kursi, serta alatalat dan media pengajaran.

Tabel 1. Fasilitas yang ada di MI Nashriyah

\begin{tabular}{rll}
\hline No. & Fasilitas & Ket \\
\hline 1. & Ruang Kepala Madrasah dan Guru & 1 Ruang \\
\hline 2. & Ruang Kelas & 6 Ruang \\
\hline
\end{tabular}




\begin{tabular}{|c|c|}
\hline 3. Ruang Perpustakaan & 1 Ruang \\
\hline 4. Wc Guru & 2 Ruang \\
\hline 5. Wc Siswa & 2 Ruang \\
\hline
\end{tabular}

Jadi bisa dipahami bahwa ruangan antara kepala madrasah dan guru yang lain tidak memiliki perbedaan, dalam artian bahwa ruangan kepala dan madrasah tergabung dalam satu lokal, ruang perpus terdiri dari satu ruang, ruang kelas 1-6, wc ada yang terdiri dari wc guru dan siswa-siswi MI Nashriyah.

Sarana pembelajaran yang ada di MI Nashriyah adalah meliputi Kurikulum:

a. Kurikulum yang dipakai di MI Nashriyah, Kurikulum nasional, Kurikulum 1984, 1994, 2004, 2006, KTSP.

b. Kurikulum sekolah adalah Kurikulum tambahan dari kurikulum nasional dalam bentuk muatan lokal, kurikulum muatan lokal di MI Nashriyah dalam bentuk pelajaran ilmu agama, seperti Baca Tulis Al-qur'an, (BTA).

2. Perkembangan Jumlah Siswa MI Nashriyah

Siswa merupakan komponen yang sangat penting dalam sebuah lembaga pendidikan, sebab tanpa siswa tidak akan berjalan sebuah lembaga tersebut, oleh karena itu siswa sangatlah urgen dalam sebuah lembaga pendidikan. Diantara peningkatan jumlah siswa yang ada di MI Nashriyah adalah:

a. Input

Dalam hal input (penerimaan) siswa di MI Nashriyah pada saat ini tidak seperti dulu lagi yakni dengan mendatangi kerumah-rumah, menawarkan agar anak mereka dapat dimasukkan di MI, akan tetapi untuk penerimaan siswa di MI orang tuanya yang datang sendiri dengan membawa persyaratan-persyaratan yang diperlukan.

Dalam pengembangan madrasah ini memang sulit jika di ingatingat sedih, sebab dulu kami yang pergi mencari siswa, naik ke rumahrumah bertanya kepada keluarga tersebut jika ada anaknya yang ingin sekolah, mohon agar kiranya anaknya bisa masuk di MI Nashriyah.

Selain itu bahwa perkembangan jumlah siswa MI Nashriyah semakin bertambah setiap tahunnya, sejak dari tahun 2006-2018 sudah mengalami peningkatan yang signifikan. (Sumber: Dokumentasi MI Nashriyah Tanjung Baru Tahun 2018) 
Pada tahun 2000 jumlah siswa yang berada di bawah pimpinan kepala madrasah A. Syarnubi sebagai berikut:

Tabel 2. Keadaan siswa-siswi MI Nashriyah pada tahun kepemimpinan A. Syarnubi

\begin{tabular}{ccccc}
\hline \multirow{2}{*}{ No } & Tahun & \multicolumn{2}{c}{ Jenis Kelamin } & Jumlah \\
\cline { 3 - 4 } & & $\mathrm{L}$ & $\mathrm{P}$ & \\
\hline 1 & $2001-2002$ & - & 4 & 4 \\
\hline 2 & $2002-2003$ & 3 & 6 & 9 \\
\hline 3 & $2003-2004$ & 1 & 2 & 3 \\
\hline 4 & $2004-2005$ & 2 & 2 & 4 \\
\hline 5 & $2005-2006$ & 1 & 2 & 3 \\
\hline 6 & $2006-2007$ & 1 & 2 & 3 \\
\hline & Jumlah & 8 & 18 & 26 \\
\hline
\end{tabular}

(Sumber: Dokumentasi MI Nashriyah Tanjung Baru Tahun 2018)

Berdasarkan data di atas bisa dilihat bahwa jumlah siswa-siswi pada pemerintahan A. Syarnubi sangat sedikit hanya berkisar 4-9 orang siswa, jadi jumlah seluruh siswa MI Nashriyah adalah 26 orang siswa. Hal ini disebabkan bahwa kepala madrasah tidak menjelaskan, mengubah seluruh aspek yang ada di MI Nashriyah, dan membangun komunikasi dengan pihak madrasah/sekolah lain maupun masyarakat sekitar sehingga mereka tidak ada keinginan untuk menyekolahkan anaknya di MI Nashriyah. Jadi, bisa disimpulkan bahwa dalam penerimaan siswa di MI Nashriyah sebelumnya memang sangatlah sulit, sebab madrasah sebelumnya benar-benar berada pada keterpurukan, sehingga sebelumnya kepercayaan masyarakat kepada MI sangatlah minim, bahkan boleh dikatakan tidak ada. Akan tetapi untuk sekarang dalam menginput siswa masuk ke MI tidak lagi seperti dulu dengan mendatangi orang tua siswa ke rumah-rumah masyarakat agar bersedia menyekolahkan anaknya di MI Nashriyah.

Jumlah siswa yang sebelumnya hanya berkisar antara 3-9 orang siswa menunjukkan bahwa keberadaan MI Nashriyah tidak diminati oleh masyarakat sekitar, hal ini dikarenakan faktor pendidikannya belum memadai, seperti guru-gurunya sedikit, gedung sekolahpun rusak, jumlah siswa-siswi sangat sedikut. Akan tetapi pada kepemimpinan kepala MI Nashriyah sekarang sudah mengalami perubahan. Berikut data tentang keadaan siswa-siswa yang masuk di MI Nashriyah semenjak awal pemerintahan Abd. Kadir. 
Tabel 3. Keadaan siswa-siswi yang masuk ke MI Nashriyah pada masa kepemimpinan Abd. Kadir

\begin{tabular}{ccccc}
\hline \multirow{2}{*}{ No } & Tahun & \multicolumn{2}{c}{ Jenis Kelamin } & \multirow{2}{*}{ Jumlah } \\
\cline { 3 - 4 } & & $\mathrm{L}$ & $\mathrm{P}$ & \\
\hline 1 & $2007-2008$ & 7 & 13 & 20 \\
\hline 2 & $2008-2009$ & 10 & 9 & 19 \\
\hline 3 & $2009-2010$ & 11 & 13 & 24 \\
\hline 4 & $2010-2011$ & 13 & 14 & 27 \\
\hline 5 & $2011-2012$ & 14 & 24 & 38 \\
\hline 6 & $2012-2018$ & 17 & 22 & 39 \\
\hline 7 & $2018-2018$ & 17 & 13 & 30 \\
\hline & Jumlah & 82 & 95 & 177 \\
\hline
\end{tabular}

(Sumber: Dokumentasi MI Nashriyah Tanjung Baru)

Berdasarkan data di atas bisa dipahami bahwa jumlah siswa yang masuk pda tahun 2008-20012 selalu meningkat secara signifikan, peningkatan pada 19-24 menunjukkan peningkatan $26 \%$, pada tahap 2427 menunjukkan peningkatan 12.5\%, pada tahap 27-38 menunjukkan peningkatan $40 \%$ sedangkan pada tahap 39-30 menunjukkan peningkatan 2\%. Sementara pada tahap 20-19 menunjukkan bahwa jumlah siswa yang masuk menurun sebesar $5 \%$ begitupun jumlah siswa yang masuk pada tahap 39-30 menurun sebesar 23,07\%. Hal ini disebabkan bahwa siswa yang masuk pada tahun pelajaran 2008-2009 ada siswa yang drop out, sebanyak 4 orang siswa.

Akan tetapi jumlah secara keseluruhan siswa-siswi MI Nashriyah terhitung dari 2006-2018 selalu mengalami peningkatan yang signifikan. Hal ini dibuktikan dalam tabel sebagai berikut:

Tabel 4. Keadaan Seluruh Siswa-Siswi MI Nashriyah Pada Tahun Kepemimpinan Abd. Kadir Sejak Tahun 2006-20013

\begin{tabular}{cccccc}
\hline No & Tahun & \multicolumn{2}{c}{ Jenis Kelamin } & Drop & Jumlah \\
\cline { 3 - 5 } & & $\mathrm{L}$ & $\mathrm{P}$ & Out & \\
\hline 1 & $2006-2007$ & 8 & 18 & - & 26 \\
\hline 2 & $2007-2008$ & 15 & 26 & - & 41 \\
\hline 3 & $2008-2009$ & 30 & 25 & 4 & 51 \\
\hline 4 & $2009-2010$ & 32 & 40 & - & 72 \\
\hline 5 & $2010-2011$ & 49 & 46 & - & 95 \\
\hline 6 & $2011-2012$ & 60 & 70 & - & 130 \\
\hline 7 & $2012-2018$ & 79 & 86 & - & 165 \\
\hline 8 & $2018-2018$ & 82 & 95 & - & 177 \\
\hline \multicolumn{5}{c}{ (Sumber: Dokumentasi MI Nashriyah Tanjung Baru) }
\end{tabular}


Jika dilihat pada tabel di atas bahwa jumlah siswa-siswi MI Nashriyah mengalami peningkatan dan penurunan hal ini disebabkan karena jumlah siswa-siswi yang masuk hanya selisih 1-3 orang yang bertambah, sehingga pada tahun 2018 jumlah siswanya secara keseluruhan berjumlah 177 dan jika dibandingkan dengan tahun 2012 hanya mengalami peningkatan sekitar 7\%. Akan tetapi yang menjadi titik tolaknya bahwa jika dibandingkan dengan kepemimpinan yang sebelumnya siswa-siswi yang sekolah ke MI Nashriyah berkisar antara 4-9 orang siswa saja.

Peningkat jumlah siswa-siswi MI Nashriyah yang masuk ke MI Nashriyah tidak hanya datang dari desa Tanjung Baru itu sendiri melainkan dari desa yang lain seperti desa Tanjung Harapan, Seri Tanjung, dan desa Ulak Kapal.

Faktor yang mendukung berkembangnya jumlah siswa-siswi di MI Nashriyah pada awalnya karena adanya pihak guru yang mempromosikan madrasah Ibtidaiyah Nashriyah sekarang sudah berbeda dari sebelumnya, sudah dilengkapi dengan gedung yang baru, setiap siswa yang masuk di MI Nashriyah mendapatkan bantuan dari madrasah tanpa kecuali, guru-guru yang menjadi tenaga pengajar di MI Nashriyah sudah memiliki stratifikasi pendidikan strata satu.

Menurut Ibu Rahimawati bahwa perkembangan MI Nashriyah dipengaruhi beberapa faktor, pertama adanya dana yang dikelola sekolah dan dibangunkan untuk kepentingan bersama, kedua adanya keinginan untuk bekerja dalam membangun MI Nashriyah, ketiga faktor peran penting kepala madrasah dalam memajukan dan meningkatkan madrasah kearah yang lebih baik.

Selain itu menurut ibu Lokon mengatakan bahwa berkembang dan bertambahnya siswa yang sekolah di MI Nashriyah disebabkan karena digratiskannya perlengkapan sekolah yang diberikan kepada setiap anak-anak yang masuk di MI Nashriyah, di bebaskannya pungutan liar, outpun dari MI Nashriyah yang sudah bisa masuk di sekolah yang berstatus negeri, proses belajar mengajar, kedisiplinan.

Sementara yang menghambat perkembangan MI Nashriyah dari aspek input siswa adalah menurut Raunah mengatakan bahwa pihak guru yang ada di MI Nashriyah pada waktu sebelumnya tidak memberikan fasilitas kepada setiap siswa yang bersekolah di MI Nashriyah, sehingga mayoritas dari masyarakat menyekolahkan anakanaknya di tempat yang lain, selain itu dikarenakan mayoritas tempat bersekolah, jadi orang tua siswa hanya mengikuti kebanyakan orang 
kemana anaknya di sekolahkan, bangunan yang ada di sekolah mendukung keinginan mereka masuk di MI Nashriyah.

Jadi bisa dipahami bahwa faktor yang mempengaruhi berkembangnya MI Nashriyah dikarenakan usaha dari pihak sekolah dalam membebaskan biaya kepada setiap anak yang mau bersekolah di MI Nashriyah, selain itu juga bahwa tidak adanya pungutan kepada anakanak yang mendaftar untuk masuk di MI Nashriyah, malahan diberikan pakaian dan diberikan bantuan dana kepada setiap anak yang bersekolah di MI Nashriyah. selain itu juga yang menghambat perkembangan MI Nashriyah dikarena belum adanya fasilitas yang diberikan kepada setiap anak yang masuk di MI Nashriyah, dikarenakan mayoritas orang tua dalam menyekolahkan anak-anaknya, melihat bangunan yang ada di sekolah itu sendiri, jadi aspek fisik menentukan mendukung keinginan orang tua dalam menyekolahkan anak-anaknya.

\section{b. Proses Pembelajaran Siswa}

Timbulnya minat dari orang tua siswa untuk menyekolahkan anaknya adalah berkaitan dengan perkembangan sekolah/madrasah tersebut. Sebab jika madrasah tidak memiliki perkembangan dan perubahan ke arah yang lebih baik, tentu tidak akan menarik minat dari masyarakat di sekitar.

Berdasarkan hasil observasi pada tanggal 17 Februari 2018 bahwa setiap kelas dimulai dari kelas I-VI menghadap/maju satu persatu ke depan untuk membaca iqra', jadi setiap siswa dibina untuk mampu untuk membaca al-Qur'an dan ini terlihat diutamakan dalam pendidikan di MI Nashriyah.

Menurut ibu Lokon Setiap anak setiap kali sebelum memulai pelajaran yang lain siswa-siswi MI Nashriyah diharuskan maju (marak) yaitu dengan menghadap ke depan untuk membaca arab dengan sistem iqra', guru memberikan reward atau nilai kepada siswa yang telah lancar dalam membaca arab. Selain itu juga guru mampu membagi siswa dalam tiga kategori yakni, kategori siswa yang memiliki kecerdasan tinggi, memiliki kecerdasan yang sedang, dan kecerdasan yang rendah. Tujuan dari hal ini agar siswa yang lain dapat termotivasi untuk masuk dalam kategori yang lebih baik lagi. Dalam hal mengerjakan tugas siswa tetap bersaing agar menjadi yang terbaik dalam kelas.

Dari hasil wawancara dengan kepala madrasah, bahwa awal mula dalam kegiatan pembelajaran yang ada di MI Nashriyah memang memprihatinkan, anak-anak di MI tidak bisa membaca dan menulis al- 
Qur'an, padahal di antara gurunya ada orang yang pandai mengaji (Qari').

Begitupun menurut Ibu Rohimawati mengatakan bahwa memang kegiatan BTA ini diutamakan sebab tujuannya adalah untuk memberantas buta huruf dalam membaca dan menulis Al-Qur'an. Sebab ini adalah ciri khas MI, maka malu jika mereka yang ada disini tidak bisa membaca dan menulis arab.

Kalau menurut kepala madrasah pelajaran yang diutamakan di MI Nashriyah adalah pelajaran berhitung (MTK), Bahasa Indonesia dan BTA. Jadi kelemahan yang selama ini terjadi di MI Nashriyah disebabkan karena faktor lemahnya dalam berhitung, berbahasa sebab untuk kelas 1-3 di MI Nashriyah masih memakai bahasa pengantar dengan bahasa ibu dan lemahnya kemampuan dalam baca tulis al-Qur'an.

Jadi bisa disimpulkan bahwa proses pembelajaran di MI Nashriyah lebih menekankan pada MTK, Bahasa Indonesia, dan BTA. Sebab anakanak MI memang diharuskan untuk bisa membaca dan menulis arab, ciri khas MI adalah bisa membaca dan menulis arab. Jadi setiap hari sebelum belajar mata pelajaran yang lain, anak-anak MI harus menghadap satu persatu ke depan untuk membaca iqra'.

Selain itu juga bahwa siswa-siswi MI Nashriyah pernah mengikuti perlombaan ditingkat madrasah maupun ditingkat kecamatan. Hal ini bisa dibuktikan dengan data sebagai berikut:

Tabel 5. Keadaan Seluruh Siswa-Siswi MI Nashriyah Pada Tahun Kepemimpinan Abd. Kadir Sejak Tahun 2006-20013

\begin{tabular}{cccccc}
\hline \multirow{2}{*}{ No } & Tahun & \multicolumn{2}{c}{ Jenis Kelamin } & Drop & Jumlah \\
\cline { 3 - 5 } & & L & P & Out & \\
\hline 1 & $2006-2007$ & 8 & 18 & - & 26 \\
\hline 2 & $2007-2008$ & 15 & 26 & - & 41 \\
\hline 3 & $2008-2009$ & 30 & 25 & 4 & 51 \\
\hline 4 & $2009-2010$ & 32 & 40 & - & 72 \\
\hline 5 & $2010-2011$ & 49 & 46 & - & 95 \\
\hline 6 & $2011-2012$ & 60 & 70 & - & 130 \\
\hline 7 & $2012-2018$ & 79 & 86 & - & 165 \\
\hline 8 & $2018-2018$ & 82 & 95 & - & 177 \\
\hline
\end{tabular}

(Sumber: Dokumentasi MI Nashriyah Tanjung Baru)

Dari data di atas bisa dipahami bahwa siswa-siswi MI Nashriyah pernah meraih prestasi pada perlombaan dibidang umum dan keagamaan, baik ditingkat sekolah maupun tingkat kecamatan. 
c. Output

Menurut ibu Lokon bahwa madrasah ini hampir mati, dilihat dari siswa-siswinya sangat sedikit yang berminat sekolah di MI, didukung pula tempatnya yang kurang layak, tenaga pengajarnya. Jadi mereka yang setelah lulus dari MI hanya diterima di sekolahan yang berstatus swasta juga seperti MTs Nashriyah, artinya untuk masuk ke sekolah yang berstatus negeri hanya dalam hayalan.

Menurut Ibu Raunah juga menambahkan bahwa MI Nashriyah memang hanya dipandang sebelah mata oleh masyarakat, seakan-akan keluaran dari MI Nashriyah tidak diterima di negeri, tidak memiliki keterampilan dan sebagainya, jadi MI Nashriyah kehilangan kepercayaan dari masyarakat sebagai lembaga tempat pendidikan bagi anak-anak mereka.

Faktor penghambat dari output siswa pada masa pemerintahan sebelumnya sehingga tidak diterima di sekolah yang lain, dikarenakan kurang komunikasi antara kepala sekolah dengan kepala sekolah yang lain, sehingga hal itu akan mempengaruhi tidak ada/minimnya kepercayaan kepada output dari madrasah Ibtidaiyah Nashriyah, sehingga semua siswa yang keluaran dari MI Nashriyah hanya diterima di sekolah-sekolah swasta, ataupun kembali di MTs Nashriyah itu sendiri.

Selain itu juga output dari MI Nashriyah tidak memiliki nilai jual, berdasarkan penjelasan kepala madrasah bahwa siswa-siswi yang ada di MI Nashriyah tidak memiliki cirri khas sebagai anak-anak yang bersekolah dari madrasah.

Jadi bisa dipahami yang melatar belakangi terhambatnya output MI Nashriyah sehingga terkadang tidak diterima di sekolah yang berstatus Negeri, dikarenakan kurangnya perhatian kepala madrasah dalam membinan dan membangun komunikasi dengan sekolah lain, selain itu juga bahwa anak-anak yang keluaran dari MI Nashriyah tidak memiliki cirri khas, sebab keluaran dari madrasah sudah seharusnya untuk mampu dalam membaca al-Qur'an.

\section{Perkembangan dari Tenaga Pendidik}

Tenaga pendidik (Guru) adalah seorang pendidik yang membimbing, mengarahkan, mengembangkan potensi peserta didik. Guru memiliki tanggung jawab yang besar dalam menumbuh kembangkan kemampuan siswa kearah yang lebih baik sehingga tenaga pendidik sangat urgen dalam Pendidikan. 
Selain itu dalam mengembangkan dan membina tenaga pendidik kepala madrasah mengadakan supervisi terhadap kinerja guru dalam mendidik peserta didiknya. Dengan supervisi akan diketahui sejauh mana tingkat perkembangan dan kinerja guru-guru yang ada di MI Nashriyah.

Menurut kepala MI Nashriyah bahwa Supervisi yang dilaksanakan secara terprogram dilakukan dalam tiga bulan dua kali, dan supervisi ini dilaksanakan pada pertengahan semester dan menjelang ujian akhir sekolah/madrasah.

Selain itu juga supervisi yang lebih dominan dilaksanakan di MI Nashriyah adalah supervisi yang bersifat dadakan, sebab menurut kepala MI Nashriyah bahwa jika supervisi selalu dilakukan secara terprogram maka guru-guru akan siap seoptimal mungkin, oleh karena itu supervisi yang lebih dominan dilakukan adalah sidak (supervisi dadakan) tujuannya agar para guru MI selalu siap dalam mengajar.

Menurut ibu Rusdiana, dalam mengadakan supervisi di MI Nashriyah kepala madrasah memanfaatkan waktu kosong ketika guru izin tidak masuk karena berhalangan, maka kesempatan inilah yang digunakan oleh kepala madrasah untuk melakukan supervisi dengan cara langsung menuju kepada siswa, menanyakan proses pembelajaran guru yang bersangkutan, mengevaluasi siswa-siswi secara langsung, dan ketika ada siswa yang belum bisa menjawab ataupun belum bisa membaca, maka guru yang bersangkutan diperintahkan kembali agar mengulangi pembelajarannya, sebab hal ini dianggap belum berhasil, ataupun kepala madrasah meninjau proses belajar pembelajaran yang sedang berlangsung dalam kelas.

Selain itu juga bahwa kepala MI Nashriyah memberikan kesempatan bagi guru-guru dan stafnya untuk mengikuti penataran, workshop ataupun seminar. Adapun penataran yang pernah diikuti oleh guru MI adalah di kabupaten.

Jadi bisa disimpulkan bahwa dalam konteks manajemen kepala madrasah melakukan kontrol sebagai tolok ukur keberhasilan seorang tenaga pendidik dalam mendidik peserta didiknya. Oleh sebab itu dalam peningkatan kualitas guru kepala madrasah melakukan supervisi dan mengikut sertakan guru dalam penatara, workshop ataupun seminar.

\section{KESIMPULAN}

Upaya yang kepala Madarasah Ibtidaiyah Nashriyah lakukan dalam mengembangkan lembaga ini adalah, pengadaan sarana dan prasarana, seperti penambahan fasilitas belajar siswa, memperbaiki sekaligus menambah gedung/lokal belajar siswa, menyediakan transfortasi khusus antar jemput 
siswa, mengawasi kinerja guru dan stafnya secara ketat, menjunjung tinggi kedisiplinan dalam bekerja.

Perkembangan MI Nashriyah di bawah kepemimpinan Kepala Madrasah Ibtidaiyah Nashriyah ini memiliki kemajuan yang pesat pada MI Nashriyah jika dibandingkan dengan sebelumnya. Dari aspek meningkatnya Pengadaan Sarana Prasarana yang ada di MI Nashriyah, seperti bertambahnya gedung, pengadaan laptop, kipas angin dan lain-lain. Disamping peningkatan sarana dan prasarana diadakan pengawasan untuk menjaga dan memelihara sarana dan prasarana yang ada di MI Nashriyah. Dari aspek meningkatnya jumlah siswa-siswa yang ada di MI Nashriyah, bahwa jumlah siswa yang masuk di MI Nashriyah setiap tahunnya mengalami perkembangan yang signifikan. Dari proses pembelajaran kepala MI Nashriyah lebih menekankan dalam pembinaan agar siswa-siswinya mampu untuk membaca dan menulis huruf arab, sehingga setiap kali sebelum memasuki pelajaran yang lain, siswa-siswi diharuskan untuk maju satu persatu membaca iqra' 1-6. Dari aspek tenaga guru (tenaga pendidik dan kependidikan), bahwa jika dibandingkan dengan tahun sebelumnya guru yang ada di MI Nashriyah juga mengalami peningkatan. Kepala MI juga selalu mengarahkan dan membimbing kinerja mereka sesuai dengan bidang keahlian mereka masing-masing. Aspek kedisiplinan meningkat hal ini bisa dibuktikan dengan absensi guru, setiap hari masuk jam 7.10- 12.15 .

\section{DAFTAR PUSTAKA}

Arikunto, S. (2007). Evaluasi Program Pendidikan. Jakarta: Bumi Aksara.

Bungin, B. (2001). Metode Penelitian Kualitatif. Jakarta: Raja Grafindo Persada. Emzir. (2010). Metodologi Penelitian Kualitatif: Analisis Data. Jakarta: Raja Grafindo Persada.

Ghozali, A. \& Fuaduddin. (2007). Kepemimpinan Kepala Madrasah Yang Efektif. Jakarta: Badan Litbang dan Diklat Pusdiklat Tenaga Administrasi.

Glasse, C. (1996). Ensiklopedi Islam. Jakarta: Raja Grafindo Persada.

Hadi, M., Djailani, A.R. Sakdiah, I. (2018). Strategi Kepala Madrasah Dalam Meningkatkan Mutu Pendidikan Pada Min Buengcala Kecamatan Kuta Baro Kab Aceh Besar. Jurnal Administrasi Pendidikan, 4 (2).

Hajijah \& Mustofa, A. (2017). Kepemimpinan Kepala Madrasah dalam Inovasi Manajemen Pendidikan Di MTs N Diwek Jombang. Jurnal Studia Manajemen Pendidikan Islam Al-Idaroh, 1(1) 138-161.

Karwati, E. \& Priansa, D.J. (2018). Kinerja dan Profesionalisme Kepala Sekolah: Membangun Sekolah yang Bermutu. Bandung: Alfabeta 
Mukhtar. (2009). Bimbingan Skripsi, Tesis dan Artikel Ilmiah: Panduan Berbasis Penelitian Kualitatif Lapangan dan Perpustakaan. Jakarta: Gaung Persada Press.

Nazaruddin. (2007). Manajemen Pembelajaran; Implementasi Konsep, Karakteristik dan Metodologi Pendidikan Agama Islam di Sekolah Umum. Yogyakarta: Teras.

Saebani, B. A. (2008). Metode Penelitian. Bandung: CV. Pustaka Setia

Sujanto, B. (2007). Manajemen Pendidikan Berbasis Sekolah: Model Pengelolaan Sekolah di Era Otonomi Daerah. Jakarta: CV. Sagung Seto.

Supardi. (2018). Sekolah Efektif: Konsep Dasar dan Praktiknya. Jakarta: PT. RajaGrafindo Persada.

Syamsul, H. (2017). Penerapan Kepemimpinan Kepala Sekolah Dalam Meningkatkan Kinerja Guru Pada Jenjang Sekolah Menengah Pertama (SMP). Jurnal IDAARAH, 1(2).

Tilaar, H. A. R. (2003). Manajemen Pendidikan Nasional: Kajian Pendidikan Masa Depan. Bandung: Remaja Rosdakarya.

Wahjosumidjo. (2010). Kepemimpinan Kepala Sekolah. Jakarta: PT. Raja Grafindo Persada. 